\title{
EDITORIAL AR'TICLES.
}

THE PRESENT ASPECT OF THE IODOFORM QUESTION. ${ }^{\circ}$

In reviewing some bacteriological papers of surgical interest in vol. iii, of this journal, ${ }^{1}$ the present writer took the ground that all suppuration was due to the presence of micro-organisms.

This maxim can, at the present time, no longer be upheld without certain modifications; since it has been demonstrated that suppuration can be produced by other means than bacteria, and especially with the help of certain alkaloids extracted from the products of bacteria.

This question of the causes of suppuration is not yet ripe for discussion, the most recent experimenters ${ }^{2}$ being at too great variance in their results.

But, curiously enough, the question of the etiology of suppuration has for some time been intimately connected with what is known as the iodoform question, and it was largely, howbeit indirectly, due to the interest excited by this question as to the efficacy of iodoform in surgical dressings, that some of the recent advances in our knowledge of the pathology of suppuration were made.

Although this latter question regarding iodoform is still, at the present date, far from being satisfactorily disposed of, yet certain new phases have been so prominently brought out by the more recent publications on the subject, that a cursory review of the more important features of the voluminous literature seems best adapted to assist in procuring for iodoform its proper place in the minds of those using it in daily surgical practice. Failing in this we may at least hope for what consolation may be gained from the knowledge that the suspicious attitude of distrust, with which many at present regard the drug, is not altogether without foundation in the scientific aspect of the problems involved in its discussion.

-The reference numbers in this paper refer to the References at the end. 
Rea ders of the ANNals will remember how Schede, in his paper on corrosive sublimate, ${ }^{3}$ related his experiences with iodoform. When he was first appointed surgeon to the Hamburg hospital and had found the typical Listerian dressing inadequate to successfully combat the influences of the unsanitary condition which prevailed in the hospital at that time, he first turned his attention to iodoform as an antiseptic dressing, in hopes of procuring primary union and an aseptic course of healing for all operative wounds. But in this hope he was greatly disappointed. For the condition and behavior of the wounds under iodoform was very much worse than it had formerly been under carbolic acid. Sepsis, erysipelas and even true embolic pyæmia occurred in the wounds treated by lodoform and, together with the anxiety caused by its poisonous properties, led to the speedy abandonment of the drug as a surgical dressing at the Hamburg hospital.

This announcement by a man of such high repute as Schede made some sensation aniong the surgeons of Germany and other countries, who, at that time, were using iodoform quite extensively and who had considerable faith in its antiseptic powers. But although many were induced by this publication to limit their use of iodoform, the majority continued to regard it with favor.

The substance was known in medicine as early as 1837,4 and had been used as a surgical dressing for ulcerative and granulating processes by various surgeons in France, England, Russia, Austria and Germany since I864. But general attention was first directed to it by the publications of von Mosetig-Moorhof of Vienna in $1880,{ }^{6}$ who recommended it as a valuable antiseptic, de-odorizing and anti-tuberculous agent, which could readily be applied to all wounds, whether recent or infected, and was well adapted for exclusive use in surgical dressings. The introduction of iodoform as a surgical dressing is therefore universally attributed to von Mosetig-Mourhof.

The consequence was that iodoform was speedily received with enthusiasm in a large number of surgical clinics and enjoyed a wide-spread reputation, which was, on the whole, but little interfered with by the publication of a number of cases of poisoning due to extensive use of the drug by a number of surgeons. 
Mikulic $z^{6}$ was the first to notice the toxic effects of iodoform and Koenig, in 1882 , published ${ }^{7}$ a collection of cases sent him by invitation $^{8}$ from various German clinics. Among the other surgeors publishing cases of iodoform poisoning are Henry, ${ }^{9}$ Schede, ${ }^{10}$ Höftmann, ${ }^{11}$ Görges, ${ }^{12}$ Pfeilsticker, ${ }^{13}$ Czerny, ${ }^{14}$ Bum, ${ }^{15}$ Kocher, ${ }^{16}$ Sands, ${ }^{17}$ Küster. ${ }^{18}$

By these and other more recent investigators the necessity of minimizing the quantities of iodoform used in surgical work was brought out, and certain contra-indications of the drug became established. These latter are youth and old age, weakened constitution, weakened circulation, and heart and kidney lesions. The symptoms of poisoning as given by Fischer ${ }^{19}$ may be clinically classed in two groups, according to whether the symptoms develop gradually or rapidly. In the first case general malaise, vomiting, loss of appetite and mental depression obtains, accompanied by some fever and rapid pulse. Gradually melancholia supervenes with loss of will-power and increasing weakness. The patients, generally aged and infirm, may die in this condition, or recovery may take place.

The second class of patients are of the robust type. Headache, vertigo, sleeplessness, high fever, very rapid pulse are the first symptoms. Deliria, as in acute mania, sudden failure of strength and coma follow in comparatively short time. The maximal dose for surgical use in healthy adults is stated to be two drachms and a half of the powder. Von Nussbaum states that fifteen to forty-five grains have been known to cause fatal poisoning, while, on the other hand, four ounces have been used in one dose with impunity.

These cases of poisoning, however, only slightly interfered, as already stated, with the extensive use of the drug; the disadvantage of its poisonous qualities, which could, moreover, be avoided by careful use, were more than counterbalanced by its virtues: its property of exsiccating wounds and minimizing the secretions; its effect of estab. lishing asepsis in all wounds; its property of preventing the development of luxuriant granulations; its de-odorizing qualities in offensive wounds; its convenience and portability as a dressing; its long continued action in wounds, etc.

All these advantages of this over other substances used for dress- 
ings had gained for it the approval and confidences of the ablest surgeons, and in most clinics it was in extensive, although careful use. The continued endorsement of it by von Mosetig-Mourhof, who in I 885 had treated over eleven thousand cases with iodoform without ever once experiencing a single case of poisoning, ${ }^{20}$ did much to gain favor for it, and among his endorsers were numbered Mikulicz ${ }^{21}$ Gussenbauer, ${ }^{22}$ Thiersch, ${ }^{23}$ Billroth, ${ }^{24}$ Schönborn, ${ }^{25}$ Leisrink, ${ }^{26}$ Koenig, ${ }^{27}$ Marc Seee, ${ }^{28} \mathrm{Küster}^{29}$ and many others. It was, however, established, and this fact was especially plainly brought out in the discussion at the Eleventh Congress of German Surgeons in $1882^{30}$ and in the celebrated debate in the Gesellschaft der Aerzte in Vienna, ${ }^{\text {sl }}$-that iodoform dressings were but little security against erysipelas.

But now, after the establishment of iodoform as a surgical dressing for more than six years, a bomb was suddenly burst in the camp of the iodoformists. For, in an experimental treatise published in the Fortschritte der Medicin, on the $15^{\text {th }}$ of January, 1887 , two Danish authors, Chr. Heyn and Thorkild Roosing, declared ${ }^{32}$ that iodoform was not only destitute of all antiseptic properties but worthless as a surgical dressing, and even dangerous to apply to wounds. This communication called forth a storm of protest both from practical sur. geons and from scientific workers, and no small amount of personal abuse from the followers of v. Mosetig-Moorhof.

Although the authors of this important paper succeeded in clearing themselves from the charge of using superficial or unscientific methods, yet the conclusions arrived at by subsequent experimenters and writers have led to the modification and partial discarding of their first deductions by the general surgical public, through the development of a series of facts of practical and even general pathological importance and by means of a number of experiments first suggested by the above mentioned treatise.

Turning our attention to the original paper by the Danish authors we find them first $(a)$ treating pure gelatine cultures of such microorganisms as fungus, staphylococcus aureus pyogenes, pneumococcus bacillus subtilis, with iodoform, covering the colonies with a layer $o$ the powder, and, after some days, inoculating culture test-tubes with 
the first colonies. In no case was the growtl of the micro-organisms in any way impeded. (b) Stcrilized gelatine ${ }^{83}$ containing iodoform powder in suspension in no wise impeded the growth of micro-organisms inoculated thereon, not even when the quantity of iodoform mixed with the gelatine amounted to 40 per cent. of the latter. (c) A fourper-cent. solution of iodoform in pure olive oil in no wise affected pure cultures of either bacillus subtilis or staph. pyog. aur., not even when the development was favored by a temperature equal to that of the normal body. Moreover the micro-organisms developed equally well on a soil composed of equal parts of iodoformised oil and blood serum. (d) Coagulated serum obtained from calf's blood and representing a saturated solution of iodoform was next inoculated with fungus, bacillus subtilis and staph. aur., and neither prevented the development of the micro-organisms nor exerted an inhibitory influence upon them. (e) A sample of staphyloccus pyog. aur. inoculated into a quantity of iodoform powder preserved its vitality unimpaired during one entire month. $(f)$ Iodoforn-spray produced by a powder-blower and directed over an expanse of sterilized gelatine, so that the surface was covered by a delicate yellow film, occasioned the growth of numerous colonies of fungi and bacteria. ( $g$ ) A tampon of iodoformed gauze which had lain in the vagina for endometritis for twenty-four hours was examined by suitable methods and was found to contain a number of bacilli and small cocci. (h) A pure culture of staphyloc. aur. pyog., which had been mixed with iodoform for a period of ten days, was injected into the joint-cavity of a rabbit and produced the same effect (suppuration of the joint) as a culture without admixture.

From these experiments the authors draw the conclusions that iodoform is not an antiseptic dressing material, and that unless a specially sterilized variety of iodoform is used, much mischief may be caused to wounds by using a powder-blower to pump air containing germs onto them, or by using a brush which may convey contagions, as iodoform itself is not capable of preventing such infections.

The first objection made to these statements, was to call the scientific ability and veracity of the authors into question. ${ }^{34}$ This attack is only of interest in so far as it demonstrates how deeply grounded the 
belief in the antiseptic properties of iodoform was with the Vienna school of surgery.

Then followed other protests of a more scientific nature, directed chiefly against the conclusions of Heyn and Roosing, which, while giving due credit to the authors for their methods and work, endeavored to point out that antisepsis might still be attained by iodoform even if it did not kill germs in the laboratory. Among these writers were Friedländer, ${ }^{35}$ Poten ${ }^{36}$ and others. Soon, too, followed a number of protests from active surgeons, who discussed the question from a purely clinical point of view, and endeavored thus to prove the antiseptic power of iodoform.

Most of the reviewers of the iodoform question, writing in periodical literature, may be mentioned here, with Koenig, ${ }^{37}$ von Nussbaum ${ }^{38}$ and Bruns. $^{39}$

The latter could prove with the help of Nauwerck ${ }^{40}$ that the tubercle bacilli present in the walls of cold abscesses disappeared after the injection of iodoform in suspension into the abscess, - a practice which enabled him to cure a very large percentage of his cases. Similar results have been reported by French surgeons. ${ }^{41}$

In the mean time bacteriological workers repeated the laboratory experiments with iodoform, and with similar results as the original experimenters, so that the correctness of their observations became established beyond a doubt. The foremost of these was Lübbert, who had previously ${ }^{42}$ worked on the subject. He now published ${ }^{43}$ his more recent experiments made with the staphyloconcus pyogenes aureus, the germ par excellence of sepsis. He found that growths of this microorganism could not be influenced by the presence of iodoform, neither in the most diverse kinds of culture media (whether capable of dissolving the iodoform or not), nor in the animal body. The number of experiments made by this author is very great, those on animals alone numbering 43, and all confirm the results gained by the Danish authors.

Sattler ${ }^{44}$ also confirms the results of Heyn and Roosing, although his paper is apparently directed against them. In over one thousand systematic experiments he proved that cultures of bacteria treated with 
iodoform in various ways could still develop and retain sufficient vitality to give rise to new cultures after their inoculation on to new soils. He found, however, that in some cases iodoform did show an inhibitory influence upon certain colonies amounting in a few cases to complete suppression of vitality, provided that the iodoform molecules could be kept in close contact with each single micro-organism, and if, at the same time conditions could be maintained which favored the decomposition of the iodoform.

Tilanus ${ }^{45}$ also endorsed the statements that iodoform frequently contains germs and is not capable of disinfecting soils used for cultures, a statement supported also by Behring ${ }^{46}$, who, however, did succeed like Sattler, in getting an inhibitory influence of the iodoform upon the cultures, provided that he could distribute it finely enough throughout the media.

Baumgarten ${ }^{47}$ who rubbed up pure cultures of anthrax bacilli and the micro-organism of the septicæmia of rabbits with the iodoform powder for halt an hour and then introduced the mass beneath the skin of rabbits, found that death followed (from mycosis of the blood) just as certainly as when no iodoform was used. Staphylococci, when mixed with iodoform and introduced in the same manner, produced abscesses.

De Ruyter ${ }^{48}$ got similar results. He too found no material influence of iodoform in preventing the development of germs on the soils, and also found germs present in iodoform; and could not prevent the death of rabbits inoculated with the micro organisms of the septicæmia of rabbits, anthrax, chicken-cholera, malignant œdema and micrococcus tetragenes, when these were mixed with iodoform. $\mathrm{He}$ did find that iodoform when dissolved in ether and alcohol (iodoform I part; ether 2 pts. ; alcohol 8 pts.) exerted an antiseptic influence and attributes the result to iodoform, parallel experiments having shown that ether or alcohol alone did not have an antiseptic action upon germs. But these results may still be due to other influences than pure iodoform.

We may sum up the testimony of all these authors in the statement that iodoform may itself contain germs which may develop under suitable conditions at any time, and that iodoform does not possess suf- 
ficient disinfectant power to kill germs in soil when mixed with them in coarse powder and in considerable quantities (up to 50 per cent of the soil). But it was not long before it was found that there did exist certain germs upon which iodoform exerted a speedily destructive influence. For Buchner ${ }^{49}$ proved that even the fumes of iodoform could inhibit the growth of plate cultures of the cholera-germ. This action became apparent as soon as a vessel containing iodoform was placed under the same bell-glass with the cultures. Fumes of pure iodine did not have the same effect.

Neisser ${ }^{50}$ calls attention to the fact that the influence of iodoform differs upon different germs. He experimented upon fifteen forms of bacteria and endorses Buchner's statements. Some bacteria, especially anthrax and those causing Koch's septicæmia of mice and rabbits, were retarded in their growth by iodoform. The staphylococci and the streptococci were in no wise affected by iodoform. These latter statements interest us here the most, as in the majority of cases in daily surgical practice our efforts are directed mainly against the germs of suppuratiou. Neisser has given us the key to understand why iodoform may do good service in some cases, but may wholly fail in others (such as in erysipelas of wounds).

Senger's ${ }^{51}$ experiments now also became known. He found like De Ruyter and others that when iodoform was introduced into a wound in rabbits at the same time with anthrax organisms, or at a later period, no antiseptic action resulted. If, however, the iodoform was first established in a wound, and later anthrax was inoculated, no poisoning resulted. Such rabbits remained healthy.

Whatever may be different in the results of experiments as to the degree of inhibitory influence exercised by iodoform in culture soils, all authors are agreed that iodoform is not potent as an antiseptic in laboratory experiments, and will not readily kill the known germs of suppuration on the soils. These facts, however universally acknowledged, are still at variance with general clinical experience. For the custom of dressing wounds of all descriptions with iodoform is still widely prevalent in spite of Schede's experiences. The question therefore presents itself as to wherein the difference between clinical observation and laboratory experiments lies. 
$A$ priori it is evident, that, granted the laboratory results may be credited, and that the clinical action of iodoform on wounds is not wholly a delusion, there exists some difference between the animal body and the culture soil, which cannot be set aside by any method of ordering the experiments, or else, that the development of bacteria in wounds is, of itself, not the cause of septic disturbance in wounds.

But as sufficient evidence had been collected by previous experimenters and observers ${ }^{5 z}$ to prove that the presence of bacteria in wounds, without the admixture of iodoform, does cause septic disturbance, there appeared for some time little hope of solving the problem. This has been latterly designated as the iodoform question, and to this the writers soon addicted themselves.

Friedländer ${ }^{35}$ had advanced the theory that iodoform exerted no influence upon the germs as such, but in some way strengthened the vital action of the tissues, so as to enable them to win in their conflict with the germs, and thus resist infection. This action attributed to iodoform he termed indirect antisepsis ${ }^{53}$. Liibbert ${ }^{43}$ also made use of the term "vital action of the body" to cover our ignorance of what was wanting in the laboratory experiments to complete the antiseptic action of iodoform. Binz $z^{54}$ recalled former experiments of his own which proved that iodine, when set free out of iodoform by submitting an oily solution of the latter to the action of the live tissues, would paralyse the mobility of the vessel-cells and prevent the extravasation of the leucocytes. In a similar manner, he pointed out, the germs might be affected in the tissues by the paralyzing influence of iodine. Poten $^{36}$ even went so far as to show how Heyn and Roosing had conducted their experiments in a manner to preclude the conversion of iodoform into pure iodine in their bacteriological experiments. These objections were subsequently answered by the Danish authors, ${ }^{55}$ who stated that they had taken no precautions to prevent the formation of iodine in their oily solutions of iodoform used. Koenig ${ }^{37}$ pointed out that the beneficial action of iodoform upon wounds, and especially upon tubercular affections, which he attested from clinical experience, might be solely due to the exsiccating action of the drug, and quoted Koch to prove that bacterial experiments are only of value when com. 
bined with clinical observation upon human subjects. He also accused the Danish authors of failing to show whether the germs cultivated in iodoformised soils had in any way become influenced in their properties by this treatment. Garré56 subsequently attacked Koenig's argument (that the chief value of iodoform consisted in drying up the wound); sufficient secretion, he said, was present even in so-called dry wounds, for myriads of bacteria to develop. This argument, that iodoform, although not antiseptic in the sense of inhibiting bacteria, could prevent their development in wounds by drying up the secretions and causing food-famine, has recently been again put forward by Jeffries, of Boston. ${ }^{57}$

The theory of the formation of pure iodine by the vital action of the tissues on the iodoform was quite a favorite one for a time, and was adopted by many reviewers and admitted into a number of textbooks. ${ }^{58}$

Another theory may also be noted here, advanced by Neudorfer ${ }^{59}$, who, believing that bacteria caused inflammation by irritation through the nervous channels, explained the antiseptic action of iodoform by its rendering the sympathetic nerve-fibers insensible to such irritations.

But now these questions began to take on a new aspect with the publications of De Ruyter ${ }^{60}$ and Behring ${ }^{46}$, who first brought into prominence the part played by the ptomaines in the presence of iodoform. De Ruyter proved by experiments that pus had the property of decomposing iodoform so that pure iodine was formed. Sterilised blood serum did not have this effect of setting free iodine out of iodoform; but as soon as septic germs (staphylococcus pyog. aur.) were added to the sterilised serum, decomposition of the iodoform proceeded as before.

Ptomaines, without germs, however, had a similar effect, and could alone decompose iodoform ; but by this action the ptomaines were themselves destroyed. In others words, iodoform exerted a chemical affinity towards the ptomaines, and a new combination resulted by which the ptomaines were rendered inactive. Behring ${ }^{61}$ pointed out how in this manner iodoform was capable of preventing suppuration, without its having a disinfecting or inhibitory influence upon the micro-organisms of suppuration. (Sattler, ${ }^{4+}$ who concluded from his ex- 
periments that the germs alone could decompose iodoform, also called attention to the fact that the ptomaines were rendered harmless by this process : he did not, however, lay stress on this latter fact in accounting for the antiseptic action of iodoform, but believed the germs were killed by the iodine). Neisser ${ }^{50}$ also believed some germs capable of alone decomposing iodoform..

If, now, this manner of explaining the effect of iodoform in keeping wounds aseptic by its action in binding the ptomaines is correct, there would no longer be a want of harmony between the laboratory experiments and clinical observation. To strengthen this supposition, however, it would be desirable to show: ( $r$ ) that germs themselves alone without ptomaines did not cause suppuration in wounds; (2) that ptomaines alone without germs could cause suppuration in the tissues; and $(3)$ that ptomaines mixed with iodoform, but without the presence of germs, would not produce pus in the animal body.

The first of these questions can be answered by a careful examination of the wounds under iodoformised dressings. For if experimental proof is at hand that iodoform can bind the ptomaines, we should here have the requisite conditions. Such examinations have been made at Mikulicz' clinic by Bassowski, ${ }^{62}$ with whom Stäheli ${ }^{62}$, of Socin's clinic, at Bâle, concurs. Bassowski found that in about one-half of all antiseptic wounds under iodoformised dressings (applied after irrigation with carbolic solution) the staphylococcus albus was present, and that in about one-third of this number limited suppuration occurred. Whenever the staphylococcus aureus or the streptococcus pyogenes occurred, however, certain suppuration was caused, the progressive character of which was dependent upon the drainage.

These experiments fail to prove our theory. We should expect bacteria to be present, but no pus. Perhaps it is permissible to suppose that the iodoformized gauze was far too far removed from the depth of the drained wound to immediately affect the ptomaines there generated.

The second and third questions have of late been answered with ac. curacy by Scheuerlen and Behring.

Scheuerlen ${ }^{64}$ boiled down extracts of four substances, a putrefying 
infusion of rabbit-flesh, a staphylococcus infusion, and two of Brieger's ptomaines, cadaverine and putrescine-and enclosed them, after sterilisation, in spindle-shaped glass tubes. These he inserted under strict antiseptic precautions beneath the skin of rabbits, and after the wound had completely healed, he fractured the tubes subcutaneously. In all cases pus was found, although in small quantities, and only at the ends of the tubes, but still unmistakable pus. No micro-organisms were found in the tissues or in the pus, and this suppuration did not evince any progressive tendency. In fact the inflammation would have been an adhesive fibrinous one, had not the ptomaines manifested their property of preventing coagulation, as was shown by the state of blood in these subjects, which would not coagulate.

Grawitz ${ }^{65}$ also experimented with cadaverine, and found that he could cause suppuration in some cases by subcutaneous injection of this sterilized ptomaine. If, however, living pyogenic organisms were added to these injections progressive phlegmons occurred with burrowing of pus. Brieger's experiments were similar in result. ${ }^{66}$

These experiments prove that pus call be generated by ptomaines alone.

Behring ${ }^{62}$ now added another link to the chain of our reasoning. He repeated the experiments of Scheuerlen with ptomaines, but included sterilised iodoform in the experiments, so that it could develop its action upon the ptomaines under the skin and beneath the healed wounds. In this case no pus was ever formed. It was therefore demonstrated that iodoform could prevent the formation of pus by ptomaines alone.

Thus far the evidence now before us points toward the conclusion that iodoform by attacking the products of bacteria can be of great practical value as a surgical dressing, and the vexed iodoform question would appear almost solved. For we need only to imagine that a few micro-organisms introduced into the tissues could be successfully combatted by the vital action of the tissues (perchance by the leucocytes and phagocytes), unless assisted in their work by the ptomaines, but that iodoform by destroying these ptomaines again supported the action of the tissues, and assisted them to victory. 
But here we must admit that we are merely theorising. For our knowledge of the modus operandi of septic infection is still very lim. ited, although we have practically demonstrated the presence of micro-organisms in all septic troubles. Why should an infection in some cases lead simply to the formation of a small local abscess, in other cases to a fatal septicæmia? The experiments upon animals done with pyogenic germs are equally inconstant, in some cases true septicæmia having been induced, in others not, and oftentimes large quantities of germs being necessary to a positive result. ${ }^{67}$

We can not expect a satisfactory answer to the iodoform question, until our knowledge of the relation of septic infections to suppuration and septicæmia is more advanced.

Moreover, the experiments with iodoform on animals quoted above still prove an obstacle to the forming of satisfactory conclusions, since they still do not harmonise with clinical experience. When micro-organisms (anthrax) were introduced into a fresh wound together with iodoform, the animals succumbed to the infection, just as when no iodoform was used. Are we to argue from this, as does Roosing6s, that the action of iodoform as an antiseptic is a chimera? We might suppose that in these cases the micro-organisms of anthrax entered directly into the circulation, where the iodoform action could not reach them. And in support of this theory we have the experiments of Senger who could not produce systemic infection with anthrax, if iodoform had been previously deposited in a wound. In this case the infection was probably not carried into such a number of newly opened lymph-spaces and blood-vessels. Again such a theory might explain von Mosetig-Moorhot's ${ }^{69}$ experiences of the easy infection of granulating iodoformised wounds by a too promiscuous and unnecessary use of probes.

On the other hand, Baumgarten could not prevent the development of local abscesses by the introduction of staphylococci mixed with iodoform into wounds. Are we here, too, to suppose a primary introduction of the germs into vessels and lymph-spaces? It appears, then, difficult to account for the clinically established potency of iodoform in rendering septic wounds aseptic, since we know from Koch that in these casec the micro-organisms crowd the capillaries. ${ }^{70}$ 
But if we cannot, with any satisfaction, theorise upon the action of iodoform in wounds, we can at least with some show of reason deduce a few practical conclusions from the mass of experimental evidence before us. Since we know that iodoform may contain germs, we should sterilise it before use; this may be done by washing it in sublimate solution. If applied with a brush to a wound the brush should not be used again. A powder-blower for iodoform should be used in a pure atmosphere only.

We will not look for an action of iodoform at a distance, an action throughout a large wound when only a portion of it is in contact with the powder, nor at the depth of a wound when only the surface is covered with iodoformised gauze.

We will not use iodotorn during a primary operation in uninfected tissues since we know that septic infection will not be counteracted by the simultaneous application of iodoform. But we will esteem iodoform for its action in preventing the subsequent infection of wounds, both during the change of dressings and in case of accidental exposure. We shall still continue to use it sparingly in granulating wounds, as we cannot dispense with its property of favorably influencing the granulations, always taking care in suppurating wounds to prevent retention by adding protective over the iodoform (v. MosetigMoorhof ${ }^{71}$ ). In wounds already septic we may use iodoform as extensively as possible, endeavoring to bring the powder into contact with every part infected. We shall not expect th to influence already existing septicæmia or pyæmia.

The greatest benefit will be derived frum iodoform by its use in operations about the mouth, vagina and rectum, where, owing to its property of destroying the ptomaines it acts as as a powerful deodorizer. For the same reason its use on putrid surfaces is to be recommended.

On the other hand, the poisonous qualities of the drug, its disagreeable odor, its irritating effect, when suspended in the air, on the mucous membranes of the eyes and nose, prevent its extended use; and since we have found in tartaric and other vegetable acids a means of rendering our sublimate solutions more active upon albuminous liquids, and in creoline (in strong solutions, 5 per cent) a means of 
keeping granulations in good condition, we are able to dispense with iodoform in all but its influence against the ptomaines, which is of so much practical value to us in our treatment of wounds of mucous membranes, and which cannot be sufficiently replaced by chlorine solutions or charcoal powder.

In conclusion we may glance at the specific action of iodoform upon other than septic germs. We have already seen that erysipelas is not in any way influenced by the presence of iodoform. Von MosetigMoorhof admits that erysipelas may attack wounds under iodoform dressings ${ }^{72}$, although he denies that it attacks iodoformised wounds more frequently than simply covered ones ${ }^{73}$.

Anthrax has been referred to. After the experiment repeated above, no surgeon will think of combatting this infection with iodoform alone.

Of the gonorrhoea-coccus Welander ${ }^{74}$ asserts that iodoform does not kill it, whlle $\mathrm{Kreis}^{i 5}$ affirms that it does so.

The question of the antitubercular action of iodoform still remains open, although this question was one of the first ones raised. The French Congress of Surgeons of this year (1888) did not occupy itself to any extent with this question. In last year's very important publication of papers on this subject by Verneuilit much attention was given to it. Raymond and Arthaud failed to get satisfactory evidence of the specific action of the drug, while Verneuil and Verchère believed to have established it. Roosing's paper ${ }^{7 i}$ is worthy of note as reporting a large number of experiments upon animals with tuberculous virus and iodoform. This author concludes that iodoform is powerless as an antitubercular agent. Clinically, however, Bruns and Nauwerck have satisfactorily demonstrated its healing influence upon cold abscesses, and in these cases the use of iodoform in ether deserves our confidence.

\section{REFERENCES.}

${ }^{1}$ Annals of Surgery, vol. iii, No. 6, pp. 507, 510.

${ }^{2}$ Nathan, Zur Aetiologie der Eiterung. Kreibohm und Rosenbach, Experimentelle Beiträge, etc. Virchow's Archiv 1888, vol. 37, pp. 737, 875 .

$=3$ Schede, Die Antiseptische Wundbehandlung mit Sublimat. Volkmann's Samml. Klin. Vortr., I885, No. 25I, 2115 . Vide ANnals OF SURgerY, I885, ii, 148. 
*Victor Wagner, Die Geschichte des Iodoforms. Arch. f. Klin. Chir. I888, 37, I, (Cogswell).

${ }^{5}$ Von Mosetig-Moorhof, Versuche mit Iodoform als Wundverbandmittel nach Operationen wegen fungöser Processe, Wien. Med. Wchnschr., I880, No. 43, 44, 46, 49, 51, p. 1172, etc., 1881 ; No. 13, 20, 21, 41. Also : Der Iodoformverband, Volkmann's Samml. Klin. Vortr., I882, No. $211,1811$.

${ }^{6}$ Mikulicz, Ueber Verwendung des Iodoforms in der Wundbehandlung und dessen Einfluss auf fungöse Processe, Wien. Med. Presse, I88I, 733 .

'Koenig, Centralblatt f. Chir, 1882, 9, 7.

${ }^{8}$ Koenig, Bitte an die Herren Kollegen, Centrbl. f. Chir., I881, 8, 8 I 7.

${ }^{9}$ Hen ry, Bericht über zwei durch Iodoformintoxication tödlich verlaufene Fälle, Deutsch. med. Wchnschr., I88r, No. 34 .

${ }^{10}$ Schede, Zur Frage.von der Iodoformvergiftung, Centrbl. f. Chir., I882, 9, 33 .

"Höhtmann, Iodoformintoxication, Centrbl. f. Chir., 1882, 9, 97.

${ }^{12}$ Görges, Zur Iodoformbehandlung, Centrbl. f. Chir., 1882, 9, 153

${ }^{13}$ Pfeilsticker, Iodoform als Verbandmittel, etc., Centrbl. f. Chir., 1882, 9, 544 .

${ }^{14}$ Czerny, Beiträge zur Iodoformvergiftung, etc., $W$ ien. med. $W$ chnschr., 1882, 32. 49 .

${ }^{15}$ Bum, Zur Frage der Iodoformintoxication, Wien. med. Presse, 1882, 23, 192, 238.

${ }^{16}$ Kocher, Iodoformvergiftung und die Bedeutung des I. f. die Wundbehandlung, Centrbl. t. Chir., 1882, 9, 217.

${ }^{17}$ Sands, On the value of iodoform as a dressing for wounds, New York Med. Record, 1882, 21, 12, 309.

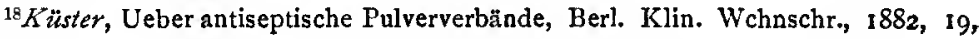
14,15 .

${ }^{19}$ Fischer, Lehrbuch der allgem. Chirurgie, stuttgart, F. Enke, 1887, p. 65.

${ }^{20} \mathrm{~V}$. Mosetig-Moorhof, Wien. med. Blätter, 1885 , No. I.

${ }^{21} M$ kulicz, Ueber den Iodoformverb, Wien. med. Presse, 1881, 22, 733. Also: Report Germ. Surg. Congress, Centrbl. f. Chir., I88I, Beil, 8.-Wien Klinik, 1882,i

${ }^{22}$ Gussenbauer, Erfahrungen über die IodoformbehandIung der Knochentuberculose, Prag. med. Wchnschr., 1881, 33, 35.

${ }^{23} \mathrm{~A}$. Beger, Bericht über die in der Klinik des Heran Prof. Thiersch in Leipzig mit Iodoform behandelten Fälle, Deutsch. Zeitrchr. f. Chir., 1881, 16, 191 .

${ }^{24}$ Mikuticz, Ueber den Iodoformverband. Report: Sitzung der K. K. Ges. der Aerzte, I881, May, 27. Also: Burl. Klin. Wchnschr, 1881, 18, 49, 721 ; 50, 741. Wölfler, Ueber die Anwendung des Iodoforms in der Mundhöhle, Centrbl. f. Chir., $188 \mathrm{I}, 48,753$.

${ }^{25}$ Falkson, Berl. Klin. Wchschr., 1881, 18, 45, 659 .

${ }^{26}$ Leisrinck, Mittheilungen aus der Chir. Abtheilungen des isrealit. Krankenhauses zu Hamburg, Berl. Klin. Wchnschr., 1881, 18, 695. 
${ }^{27}$ Koenig, Das Iodoform als antiseptisches Verbandmittel, Centrbl. f. Chir., I88I, 8,755 .

${ }^{28}$ Marc Sèe, etc., Gaz. des hôp., 1881, I39, I1 10. Also : ibid, 1882, 62, 531 .

${ }^{29}$ Küster, Ueber Stillung arterielle Blutungen durch antiseptische Tamponade,etc.,

Berl. Klin. Wchnschr., 1883, 20, 48, 737 .

${ }^{30}$ Report, Centrbl. f. Chir., I882, Beilage.

${ }^{31}$ Report, Anzeiger der K. K. Ges. der Aerzte in Wien, 5-12, 3. Nov. 1882, 4 Jan. $188_{3}$.

${ }^{32}$ Chr. Heyn und Thorkild Roosing, Das Iodoform als Antisepticum. Fortshritte der Medicin, $1887,5,33$.

${ }^{33}$ For explanation of technical terms and description of bacteriological methods vide ANNALS OF SURGERY, I886, 3, 43 .

${ }^{34} R$. W. ( $R$. Wittlefhoefer), Das Iodoform als Antisepticum, Wien. med. Wchnschr., 1887, No. 6. Also : Fortschr. d. Med., 1887, 5, Beil., 33.

${ }^{35}$ Friedländer, Das Iodoform als Antisepticum, etc., Fortshr. der Med., 1887, 5 129.

${ }^{36}$ Paten, Bemerkungen zu den Iodoformuntersuchungen, Fortschr. der Med. 1887, 5, I3I.

${ }^{37}$ Koenig, Ueber die Zulässigkeit des Iodoforms als Wundverbandmittels, etc, Therap. Monatshefte, 1887,4 .

${ }^{38}$ V.Nussbaum, Leitfaden zur antiseptischen Wundbehandlung, etc, Stuttgārt. F. Enke, 1887.

${ }^{39}$ Bruns, Ueber die antituberculöse Wirkung des Iodoforms, Therap. Monatshefte, I 887,5 .

${ }^{40}$ Bruns u. Nauzverk, Ueber die antituberculöse Wirkung des Iodoforms, Bruns' Beiträge zur Klin. Chir., 1887, 3, Hft. I.

41 Holstein, Les injections d'ethér iodoformé dans le traitement des abscès froides. Thèse. Paris, 1887.

${ }^{42}$ Lübbert, Biologische Spaltpizuntersuchungen, Würzberg, Stahel, 1886.

${ }^{43}$ Lübbert, Ueber das Verhalten von Iodoform zum Staphlococcus pyogen., aur., Fortschr. d. Med. 1887, 5, $33^{\circ}$.

4Sattler, Ueber den antiseptischen Werth des Iodoforms und Iodols, Fortschr. d. Med. $1887,5,362$.

45̄Tilanus, Ist Iodoform ein Antisepticum? Münch. Med. Wchnschr., I887, 34, 309 .

${ }^{46}$ Behring, Ueber Iodoform und Acetylen, Deutsche Med. Wchnschr., 1887, 20, 422.

${ }^{47}$ Baumgarten, Ueber das Iodoform als Antisepticum, Berl. Klin, Wchnschr.,1887, 24, 354.

${ }^{48}$ DeRuyter, Zur Iodoformfrage, Arch. f. Klin. Chir., 1887, 35, 213.

${ }^{49}$ Buchner, Ueber die Einwirkung der Iodoformdämpfe auf den Cholera-Vibrio Münch. med. Wchnschr., I887, No. 25 . 
${ }^{30}$ Neisser, Zur Kenntniss der antibacteriellen Wirkung des Iodoforms, Virchow's Arch., 1887, 1 10, 281, $3^{81 .}$

${ }^{51}$ Senger, Report, German Congress of Surgeons, Centrbl. f. Chir., I887, Beilage. ${ }^{52} \mathrm{Vi}$ ''e Article on Sepsis, AnNals of SurgrRy, 1886, 3, 321 .

${ }^{63}$ Gottstein, Review, Fortschritte der Med., 1887, 5, 83.

${ }^{54}$ Binz, Zur lodoformfrage, Therap. Monatshefte, 1887, 5 .

${ }^{55}$ Heyn u. Roosing, Gegenbemerkungen an Dr. Poten, Fortschr. der Med., 1887, 5, 203.

${ }^{66}$ Garré, Review, Correspondezbl. Schweiz. Aerzte, 1887 , No. 11.

${ }^{57}$ Jeffries, The antibacterial action of iodoform, Amer. Jour. Med. Soc., I888, Jan.

${ }^{58}$ Fischer, Lehrbuch der allgem. Chir., 1887, F. Enke. Stuttgart.

${ }^{59}$ Neudörfer, Gegenwart u. Zukunft der Antiseptik, und ihr Verhaltniss zur Bacteriologie, Klinische Zeit-und Streitfragen, Wien., 1887.

${ }^{60}$ DeRuyter, Report, 16 Congress of German Surgeons, Centrbl. t. Chir., 1887, Beil.

${ }^{61}$ Behring, Cadaverin, Iodoform und Eiterung, Deutsch. med. Wchnschr., 1888, 32, 653.

${ }^{62}$ Bassowski, Ueber das Vorkommen von mikro-organismen in Operationswunden unter dem antiseptischen Verbande, Wien. med. Wchnschr., 1887, No. 8, 9.

${ }^{69}$ Stäheli, Dissertation, Basel, 1886.

${ }^{64}$ Scheuerlen, Weitere Untersuchungen über die Entstehung der Eiterung, ihr Verhältniss zu den Ptomainen und zur Blutzerinnung, Arbeiten a. d. Chir. Klinik der Univ. Berlin. Pt., 3 .

${ }^{65}$ Grawitz, Ueber die Bedeutung des Cadaverins für das Entstehung von Eiterung, Virchow's Arch., t 10.

${ }^{66}$ Vide also Leber Ueber die Entstebung der Entziindung und die Wirkung der Entzändungserregenden Schädlichkeiten, Fortschr. d. Med., 1888, 6, 460.

${ }^{67}$ Fehleisen, Zur Aetiologie der Eiterung, Arbeiten a. d. Chir. Klinik, der Univ Berlin,, vol, iii.

${ }^{68}$ Roosing, Bemerkungen in Bezug auf deRuyter's Iodoformuntersuchungen, Fortschr. d. Med., 1888, 6, 569 .

${ }^{69}$ Von Mosetig-Moorhof, Das sondiren granulirencer Wunden, Wien. med. Presse, I 888, 29, 506.

70.ANNALS OF SURGERY, 1886, 3, 321 .

71 Von Mosetig-Moorhof, Vorlesungen über Kriegschirurgie, 1887, Wien und Leipzig, Urban und Schwarzenberg. Also: Die Bedeutung des Scharfverbinderaden Wundveıbandes, Wien med. Presse, 1887, No. 6.

${ }^{72}$ T'on Mosetig-Moorhof, Bericht des K. K. Krankenhauses Wieden vom Solarjalır, ı886, Wien., I887.

${ }^{73}$ L. Frey, Iodoform und Erysipel., Wien. med. Presse, 1887, No. 49, 50.

74 Welander, Hygiea, $1885,47,1,1$. 
${ }^{75}$ Kreis, Beiträge zur Kentniss der Gonococcen, Wien med. Wchnschr., 1885 , No. 30, 31, 32, p. 939 .

${ }^{76}$ Études expérimentales et cliniques sur la tuberculose. Publiées sous la direction de M. le prof. Verneuil, Paris, 1887 .

${ }^{7 T}$ Roosing, Hat das Iodoform eine antituberculöse Wirkung? Fortschr. d. Med.. $1887,5,257$.

W. W. Van ARsDale. 